\title{
How to measure customer value and its relationship with shareholder value in a business-to-business market
}

\author{
Gustavo Bermejo, Carlos Rodríguez Monroy \\ Madrid Technological University - ETSII-UPM (Spain) \\ gustavo.acome@telefonica.net, crmonroy@etsii.upm.es
}

Received August, 2009

Accepted October, 2010

\begin{abstract}
:
Intangible assets are difficult to measure, but nowadays the value of the shares of firms in the stock exchange market contains a high percentage of intangible capital and customers are one of the main intangible assets that should be evaluated. This paper presents and discusses some tools to measure the value of customers. But first, it is mandatory to define and clarify the relationships among the concepts of Customer Equity (CE), Life Time Value (LTV) and Customer Relationship Management (CRM). LTV is the best financial outcome to measure customer value, so the paper reviews the literature on some mathematical models to calculate LTV. We propose an equation for LTV in order to apply it in a business-to-business market, and an analysis of the influence factors involved in it is made, focusing especially on the link between LTV and shareholder value. Finally, we propose as future lines of research, the relational equity approach as the perfect complement to the customer equity analysis and a way to estimate LTV for actual cases of publicly traded firms using published information.
\end{abstract}

Keywords: customer equity, life time value, customer relationship management, shareholder value.

JEL Codes: M31 


\section{Introduction}

Customers are important intangible assets, but being intangible it is difficult to assign them a value. How can we measure the value of our customers? What aspects should we consider to plan business processes which allow us to have better customer segmentation, high profitability and create more value for our firm? These are the two main questions that this article tries to answer focusing on a business-to-business market, and linking the marketing perspective with the financial perspective. To achieve this, we have reviewed recent literature concerning the "customer value", "CRM", "customer equity" and "customer profitability" concepts. In any case, in order to focus the main target, it is mandatory to begin with the seven dimensions that any marketing measurement should take into account (Seggie et al., 2007). These dimensions are: financial, forward looking, long-term, micro, relative, causal and objective. The financial dimension gives an economic value of the profitability of marketing and commercial policy. The forward looking dimension reflects expected profits. Long-term focuses on the effect of the future in marketing policy and in the sustainability of competitive advantage. The micro dimension is focused in customizing particular policies for each customer or market segment trying to get better forecasts and decisions. The relative dimension gives the position of the firm in the market by comparing with competitors to keep sustainable competitive advantage as a source of value. The causal dimension provides the relationships between marketing actions and financial returns. Finally, the objective dimension expresses the wiliness of tracking, controlling and planning activities and results in objective results.

The Customer Equity (or Customer Lifetime Value or Customer Profitability) approach is focused on the customer value and measures it as the sum of customer life time values (LTV model) which cover past, present and future values. This approach gives us a quantitative result (financial) of the value of the customers and it is classified in the operational level of the framework. Some mathematical models are reviewed, and we propose one of them as the most appropriate for a business-to-business market, analyzing the components of the equation. But, in our understanding, this approach should be completed with the relational equity approach, which involves "the wealth-creating potential that resides in the firm's relationships with its stakeholders" (Sawhney \& Zabin, 2002). 
With customer and relational equity, we can cover six of the seven dimensions, the exception being the relative dimension. Due to the complexity of this dimension, we have considered that it should be analyzed in another paper. Relational equity gives a double perspective of value: "per se" and as a way to analyze and create value. It covers a qualitative and strategic level, and provides an assessment of the customer which is more functional than economic. It is a perfect complement which helps to calculate and understand the drivers of the future value of customer equity in the firm. The concept of customer value is in the first line of this paper as the answer for the two initial questions and in our understanding it should be linked with the concept of shareholder value as the final quantitative expression of "value" created in a firm.

\begin{tabular}{|l|l|l|l|l|l|l|l|}
\hline & & EVA & $\begin{array}{l}\text { Balanced } \\
\text { scorecard }\end{array}$ & $\begin{array}{l}\text { Brand equity } \\
\text { (financial } \\
\text { perspective) }\end{array}$ & $\begin{array}{l}\text { Brand equity } \\
\text { (consumer } \\
\text { psychology } \\
\text { perspective) }\end{array}$ & $\begin{array}{l}\text { Relational } \\
\text { equity }\end{array}$ & $\begin{array}{l}\text { Customer } \\
\text { equity }\end{array}$ \\
\hline 1 & Financial & Yes & Partial & Yes & No & Partial & Yes \\
\hline 2 & Forward looking & No & Partial & Yes & No & Partial & Yes \\
\hline 3 & Long-term & No & Partial & Yes & Partial & Partial & Yes \\
\hline 4 & Micro & No & No & No & Partial & No & Yes \\
\hline 5 & Relative & No & No & No & No & No & No \\
\hline 6 & Causal & No & No & No & No & No & Yes \\
\hline 7 & Objetive & Yes & Partial & Yes & No & Partial & No \\
\hline
\end{tabular}

Table 1: Existing approaches to measurement critiqued on the seven dimensions (Seggie et al., 2007)

\section{Customer Relationship Management, Customer Equity and Customer Lifetime Value: concepts to review}

In order to focus on the concept of "customer value", it is interesting to begin with the clarification of the relationships among the concepts of "CRM", "customer equity" and "customer lifetime value". Customer relationship management is known as CRM and may be defined as the "management of mutually beneficial relationship(s) from the seller's perspective" (Richards, 2008). CRM definitions are usually classified in two categories: strategic and operational. From the strategic point of view, CRM aligns business processes with customer strategies to build customer loyalty and increase profits over time (Rigby et al., 2002). From the operational point of view, we can define CRM as a "systematic process to manage customer relationship initiation, maintenance, and termination across all customer How to measure customer value and its relationship with shareholder value... 
contact points in order to maximize the value of the relationship portfolios" (Reinartz et al., 2004). We take this last category as the origin of the focus of this paper. In this way, the necessity of measuring CRM leads to the concept of "customer equity" as the measurement of CRM outcomes.

Therefore, customer equity (CE) is concerned with identifying the value of the whole base of customers for the seller. According to this idea, Richards and Jones consider that "measuring CE provides an indication that a margin is generated above and beyond both the product costs and the costs to sell those products to a group of customers". In the calculation process for $\mathrm{CE}$, individual customer lifetime values (CLV) or life time value (LTV) are determined for each customer and ultimately $C E$ is related to a return on marketing measurement. Customer lifetime value is defined as the net present value (NPV) of a single customer's value and CE is defined as the discounted sum of each customer's LTV less any on-going investments required to maintain customer relationships. There are some mathematical models to express this concept depending on the characteristics of the market (business-to-business or business-to-consumer).

Although customers are intangible they should be managed as assets that should allow maximizing their total base, not only one particular customer or set of them. CE centralizes the optimization of the value of the firm's entire customer base. This value is affected by the acquisition of new customers, the retention of current customers, and the increase of up-selling and cross-selling of new services or products to current customers. CE is a financial parameter.

Rust et al. (2000), establish three types of equity which are antecedents to customer equity: value equity, brand equity, and relationship equity. Value equity is the customer's assessment of the brand based on its utility. Customers evaluate what is given up and what is received to determine this aspect of equity.

Managers have three levels that have an impact on value equity: the customer's perceptions of quality, price and convenience. This type of equity is the basis to establish long-term relationships. Without the perception that the customers receive a positive trade-off between costs and benefits, there will be little motivation for the customers to make repeated purchases. 
Brand equity is a more subjective consideration of the brand and is more concerned with image and meaning than the rational evaluation of price, quality and convenience (Lemon, et al., 2001; Rust et al., 2000). Brand equity is driven by brand awareness, the attitude towards the brand and corporate ethics. Each of these elements contributes to improve the customer's perception of the brand and increase attraction and retention rates.

Finally, relationship equity comprises the special relationship elements that link the customer to the brand and serve to set up the relationship above and beyond value and brand equity. Relationship equity represents the impact on the customer from the company's attempts to build relationships and operate retention programs (Lemon et al., 2001; Rust et al., 2000). A customer's evaluation of loyalty programs, affinity programs, community-building programs, and knowledgebuilding efforts (e.g., personal selling relationships) is captured to measure relationship equity. The three drivers of $\mathrm{CE}$ : value, brand and relationship equity, will be used to classify measurable CRM outputs and to carry the benefits of CRM through to CE. Richards and Jones (2008) identify these seven core benefits of CRM as a set of value drivers for CRM (left column in Figure 1).

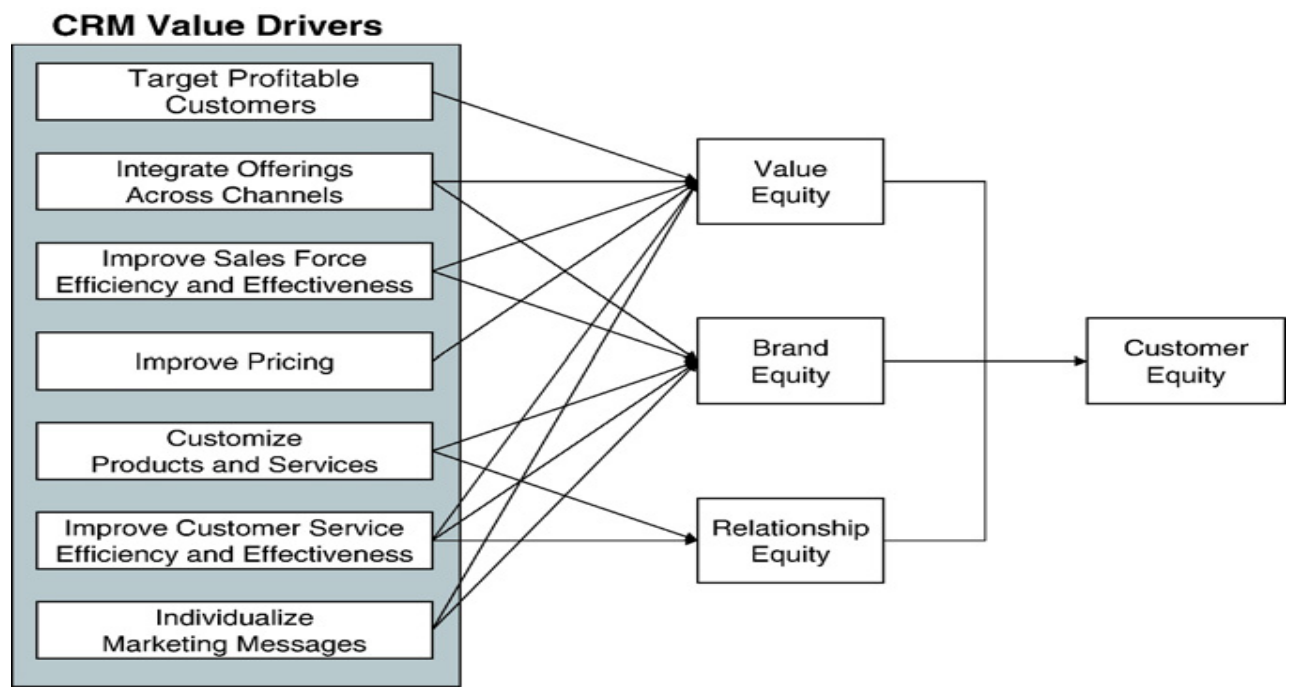

Figure 1. Components of Customer Equity (Richards, Jones, 2008).

\section{Customer Equity}

Stahl et al. (2003) argue that the metrics based on accounting profitability used traditionally as the expression of the value of the firm, do not reflect adequately 
this profitability and value. This is because accounting methods differ from each other, risks are not measured, investment requirements are not reflected, dividend policy is inexistent and the time value of money is not taken into account. Therefore, the market value of a firm comes from its Net Present Value (NPV) of its future cash flows generated by its assets, discounted at the adequate interest rates and adjusted by risk and inflation. Shareholder value should be evaluated in relation with the strategies and initiatives that could generate NPV of future cash flows.

According to this idea, Stahl et al. (2003) propose that customers have to be treated as assets that increase shareholder value by processes that accelerate (earlier cash flows produce a higher present value of money) and enhance (increasing revenues and/or reducing costs, working capital and investments) cash flows, reducing cash flow volatility and vulnerability (lowering the cost of capital) and increasing the residual value of the firm (through processes). As we explained in the previous section, customer equity reflects the value of the whole base of customers for the seller. In this way customer equity is the best approach to this concept through measuring LTV and it should be clearly linked with shareholder value. And shareholder value, as we indicated above, is the best financial expression of the concept of "value" created in a firm.

In addition, customer equity is based on customer relationships, which should be viewed as investment decisions and customers as generators of revenue flows. Customer relationships also generate costs. According to Stahl et al. (2003) there are some empirical studies which contradict the generally accepted idea that $20 \%$ of the customers generate $80 \%$ of the profits and that many of the remaining customers generate losses. It is therefore important to measure the true value of a customer. There are many definitions of LTV given by some researchers (Berger \& Nasr, 1998; Blattberg \& Deighton, 1996), but the most common definition is LTV as the sum of the revenues gained from the company's customers over the lifetime of transactions after the deduction of the total cost of attracting, selling, and servicing customers, taking into account the time value of money. The calculation is based in Net Present Value (NPV) obtained from customers over the lifetime of transactions. 


\section{A Literature review about LTV models: research focus}

The focus of most LTV studies has three main orientations (J ain \& Singh, 2002):

1. The first one is the development of models to calculate the LTV for each customer.

2. The second one is described as "customer base analysis" with some methods to analyze the information about the customer portfolio and predict the probabilistic value of future customer transactions.

3. The third one, it is to analyze LTV and its implications for managerially relevant decisions through analytical models (normative models of LTV), especially loyalty programs for LTV and firm's profitability.

In relation to the models to calculate LTV, we follow the classification proposed by Jain and Singh (2002) who consider four main models:

1. Basic structural model: based on the NPV obtained from the customers but without taking into account acquisition costs, prospective customers, and the stochastic nature of the purchasing process. Berger and Nasr (1998) take this model as the basis to build others.

2. Customer migration model: it is proposed by Dwyer (1997). He divides industrial buyers in two groups-"always-a-share" and "lost-for-good"-. For "always-a-share" customers, Dwyer describes a customer migration model using purchase history (past purchase behavior) to predict purchase behavior. Depending on the number of purchase periods and recency cells, a general matrix of purchase propensity is produced, which represents a probabilistic nature of customer purchases. For "lost-for-good", the model is a customer retention problem, so the basic model is the best for this. The model is not indicated for uncertain revenue flows.

3. Optimal resource allocation models: Blattberg and Deighton (1996) propose a managerially relevant model for finding the optimal balance between spending on customer acquisition and customer retention in order to maximize LTV. Customer equity gains and losses could be tracked through marketing programs. The weakness of this model is that it does not 


\section{- Intangible Capital}

consider customer acquisition and retention jointly to maximize customer equity.

4. Customer relationship models: Pfeifer and Carraway (2000) propose a general class of mathematical models called Markov Chain Models (MCM) as appropriate for modeling customer relationships. MCM can be used to model both customer retention and customer migration situations. The key elements of MCM are the transition probability matrix and the reward vector. MCM are the most flexible models, but probabilities are not easy to compute.

With respect to "customer base analysis", there are some models that take into account the past purchase behavior of the entire customer base in order to calculate probabilities of purchase in the next time period. These models take into consideration the stochastic behavior of customers in making purchases and consider each customer individually to compute the probability of purchase in the next time period. We can consider the Pareto/NBD model proposed by Schmittlein et al. (1997) as the main one, although there are some extensions of it such as the framework proposed by Reinartz and Kumar (2000). The problem of these models is the difficulty to get all the data and the calculation of the probability. They are not very easy to apply to real situations in a firm.

Concerning normative models, they give us the opportunity to analyze empirical validation of many LTV models. There are two main ones: "customer equity model" and "a dynamic pricing model based on LTV". Both of them have been proposed by Blattberg and Thomas (2000).

\section{The LTV model: an equation proposed for business-to-business markets}

Before developing the LTV model, it is necessary to describe shortly the main characteristics of business-to-business markets. According to Lindgreen and Wynstra (2005) these markets appear like relatively well-organized connected systems or networks:

1. They consist of a few important actors, buyers, and sellers who can strongly influence the market. 


\section{- Intangible Capital}

2. In recent last years, there has been a concentration process reducing even more the number of actors which have become more complex and global due to a higher pressure in reducing costs, concentration in main cores of each player, more innovations (especially in services) and attempts to reduce the "time-to-market" of products and services.

3. There are important dependencies among actors and this implies that those actions, which take place within a specific business relationship, influence and are influenced by actions within other relations.

4. They are rigid, i.e. it is difficult to change supplier and/or to get new customers, since it involves a more or less well-organized system of actors, activities, and dependencies.

5. They lead to a relationship-oriented approach.

6. Activities of the selling (buying) company are thus aimed at specific customers (suppliers) instead of aiming at large market segments. The content and function of the specific relationship are emphasized, but especially the relation's function in the larger network will be put into focus here much more than in the type of market described before.

7. The demands on the marketing or purchasing function's competence consequently become more complex and functional, production, technical and market-related aspects need to be assessed. In this situation, in the short-term, it is very difficult to change counterparts, and work will instead be directed towards building the relationship, learn about the other party, and so on. This would tie in very closely with assessing the value of relationships. Relevant commercial competences should be focused on understanding the industrial network's way of functioning and ability for network-oriented behavior. For the technical aspects of the transaction, competence in the wider functional aspects of the product/service becomes relevant.

In this kind of markets, the figure of the Key Account Manager (KAM) plays a major role in the relationships between suppliers and customers (Muruais \& Rodríguez Monroy, 2009). His impact is due to the fact that the KAM is directly responsible for creating direct value for the firm through managing the customers. But the KAM How to measure customer value and its relationship with shareholder value... 


\section{Intangible Capital}

not only creates "direct financial value", but "indirect value" as well in the sense proposed by Walter and colleagues (2001). Therefore, the KAM's participation in calculating future revenues and potential risk is a key issue.

As we have described in the literature review, there are some mathematical models to calculate LTV depending on the type of market, but most of them, although they propose complex mathematical formulas, do not solve the problem of predicting future purchase behaviors of customers and they are difficult to apply in real situations. On the other hand, taking into account the structure and characteristics described for a business-to-business market above, where in general, there are not many customers and they are well known by the KAM of the firms, we prefer a general and simple one which could be based on four components (Stahl et al., 2003) which are possible to estimate:

1. Base Potential: cash flow from products and services that form the core of the relationship. Costs of acquisition, development and retention are estimated over the expected duration of the relationship.

2. Growth Potential: cash flow from cross-selling, up-trading, a higher "share of the wallet", etc.

3. Networking potential: cash flow from new relationships through customer's word-of-mouth referrals. Referrals have a double effect. First, they may lead to additional sales and lower acquisition costs as new customers are attracted through word-of-mouth advertising. Second, referrals can increase the effectiveness of advertising and promotion because customers develop a more favorable attitude towards the firm's communication.

4. Learning potential: cash flow from knowledge created through interaction within the relationship. This knowledge could be: market conditions (competitors, customers, channels, suppliers, and social and political interest groups), technologies and business processes or future trends. These types of knowledge can be transferred into more reliable forecasts and plans providing a better understanding of current and future customer needs and consequently leading to higher quality of products and processes. 


\section{Intangible Capital}

These components reflect the behavior of the business-to business market like a network. Therefore, taking into account these components, we propose the formula of Stahl et al. as a basis to calculate LTV (cf. equation 1).

As we have explained above, many companies assume that customers with the highest volume of transactions are the most profitable customers and believe in Pareto's Law. But, typically the highest volume customers also make use of the greatest bargaining power, thus enjoying the lowest prices at a high level of pre and after sales services. On the other hand, low-volume customers generally pay the highest prices but may absorb even more sales and service resources than high volume customers. As a result, medium-volume customers tend to be the most profitable.

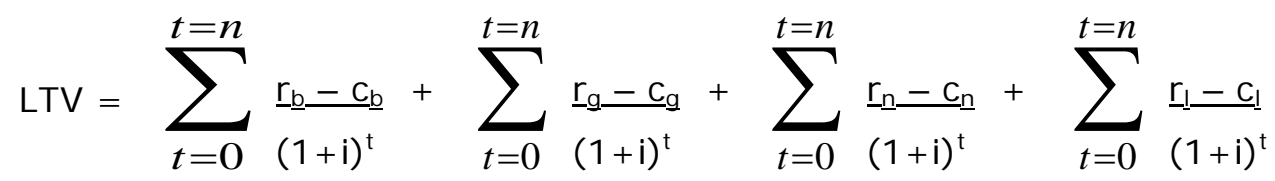

Equation 1. LTV (Stahl et al., 2003)

Where:

$$
\begin{array}{ll}
r=\text { Expected Revenue } & \text { Subscripts: } \\
\mathrm{c}=\text { Expected Cost } & \mathrm{b}=\text { Base Potential Term } \\
\mathrm{i}=\text { Discount rate, WACC } & \mathrm{g}=\text { Growth Potential Term } \\
\mathrm{t}=\text { time } & \mathrm{n}=\text { Networking Potential Term } \\
\mathrm{n}=\text { lifetime to consider } & \mathrm{I}=\text { Leaning Potential Term }
\end{array}
$$

Stahl et al. (2003) maintain that in many cases, low-maintenance customers subsidize those with high service demands. To avoid this and improve the profitability of customers' portfolio, customers need to be treated as a bundle of costs drivers. This is precisely the principle of Activity Based Costing ( $A B C)$ which provides a fairly accurate means of measuring costs related to customer relationships. 
Both monetary and nonmonetary benefits have to be taken into account, and this is related to the concept of value.

\section{An analysis of the factors involved in the equation proposed to measure LTV in a business-to-business market}

As it is logical to imagine, the most difficult aspect of the LTV equation is to calculate the future revenues (base and growth potential) and the effects of relationships with the market (learning and networking potential) in an accurate way. Therefore, since they are intangible elements and consequently difficult to estimate, it requires a deeper analysis of the factors which have an influence in the calculation.

To begin with, LTV analysis demonstrates that the value of the relationship with a customer can be increased either by increasing the amount of profit or by extending the relationship's lifetime, managing the relationship with the customer. Hence, the first factor to analyze is profit and we can say that the amount of cash flow (revenues) generated by a customer's relationship depends on sales volume, price and costs. These costs comprise the acquisition costs (advertising, product specifications, etc.), the relationship costs (routine costs associated with serving the customer) and the retention costs (the costs of defending, strengthening and expanding relationships).

Relationship costs are influenced by the amount, frequency and specificity of transactions, that is, by economics of scale and experience curve effects. Cash flow can be accelerated by faster product development (by involving its most demanding and knowledgeable customers), a more efficient supply chain management and a quicker diffusion of new products in the marketplace (innovators and early adopters and customers with high brand awareness and favorable brand attitudes as target). These elements accelerate the time-to-market and market acceptance (Stahl et al., 2003).

The second factor to analyze is the lifetime of customers. If we extend the lifetime, the probability of fluctuations in revenues and costs over the duration of a customer's relationship increases. Long-term customers are not necessarily profitable customers. The costs and revenues depend on the nature of the 
customer relationship. Exchange efficiencies might be lower since the company must ensure that the relationship stays alive.

The longer the time horizon of the customer value analysis, the more purchase cycles are incorporated, and this increases uncertainty. Therefore, the risk of each relationship in terms of volatility and vulnerability must be estimated (Stahl et al., 2003). This increases the cost of capital. Consequently, the discount rate is higher, so the resulting LTV is lower.

According to Stahl et al., vulnerability is defined as occurrences that negatively affect cash flow streams, whereas volatility refers to occurrences that create fluctuations in cash flows. We can consider three levels of risk that can cause vulnerability and volatility: macro environment, industry and firm. We should add the "share of wallet".

At the industry level, vulnerability and volatility of cash flows is influenced by competitive forces. Growth rates, mergers and acquisitions, market entry barriers, substitution threats, threat of new entrants, etc. are major sources of risk. Similarly, quality of management, investment decisions, the nature and stability of customer-supplier relationships and so on can also affect volatility.

The "share-of-wallet" risk is directly related to the buying behavior of the customer. There could be two groups of industrial buyers: always-a-share and lostfor-good customers. These last ones have typically made long-term investments and face high switching costs. They are either totally committed to the company or totally lost to another vendor. The first ones spread their purchasing volume over several vendors. They display a rather opportunistic buying behavior.

The third factor to analyze in the LTV equation is the influence of the discount rate chosen. Unfortunately, even if LTV calculations show a positive return, it is possible that a customer relationship could destroy shareholder value. One reason for this is that commonly-used profit measures do not necessarily reflect shareholder value creation because they do not take into account the true cost of capital (Ryals \& Knox, 2007).

The weighted average cost of capital (WACC) takes the average cost of equity determined by the return its investors require on the money they invest in the business. It is only if the return on capital exceeds the cost of capital that an How to measure customer value and its relationship with shareholder value... 


\section{Intangible Capital}

investment creates shareholder value. But WACC is externally determined and reflects the lenders' view. However, discount rate is determined internally and reflects the company's own view of its risk. There is a difference in calculating LTV using WACC or discount rate. The longer the predicted LTV, the greater the impact of a change in discount rate on the net present value.

Linking marketing investments to shareholder value requires the use of weighted average cost of capital rather than discount rates and the measure of risk and returns from customers.

There are two ways of adjusting risk accountability in customers (Ryals \& Knox, 2007):

1. The WACC discount rate used to calculate LTV can be further adjusted for the risk associated with one particular customer; or

2. The risk evaluation can be expressed as a probability of obtaining the forecasted future flow of revenue from that particular customer.

Customer risk is expressed as the probability of securing customer lifetime value. This risk is assessed through key account profiling so that the shareholder value generated by CRM investments can be estimated.

Customer risk factors: internal CRM capabilities, general insights about their customers and information about the market such as growth potential, customer defection rates and competitive intensity. Each factor is then assigned an importance weighting and customers are scored against these factors and a risk scorecard is built.

The main risk in major account relationships is the total loss of the customer or reduction in a customer's "share of wallet" (Ryals \& Knox, 2007). The probability of each risk factor is at least partially subjective.

The shareholder return is optimized depending on a thorough understanding of the customer's strategy, its market position, and the supplier's own CRM skills and competencies. 


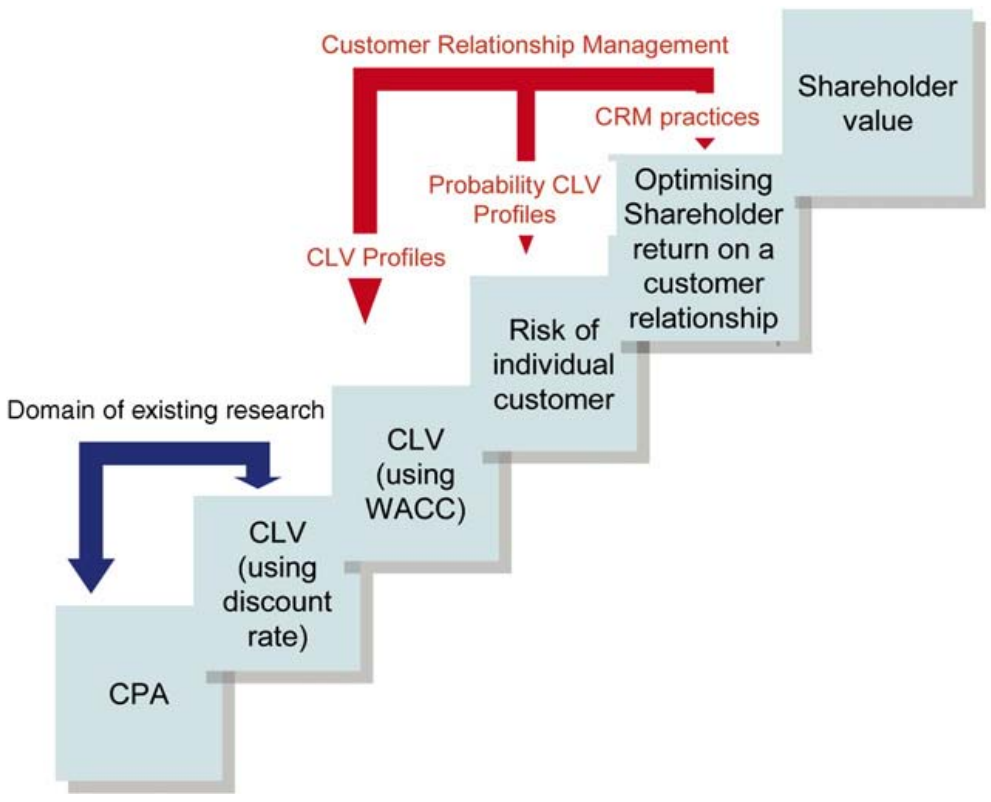

Figure 2. Linking CRM and LTV with shareholder value (Ryals \& Knox, 2007)

Business-to-business relationships are characterized by the interaction of many individuals at different levels with a complex network behavior; thus, information on technical requirements, customer satisfaction, and unsatisfied needs and so on is dispersed throughout the organization. Such evaluations should involve individuals from different functions who are most able to accurately assess the growth potential. These individuals are usually the KAM who have the direct relationships with the customers (Muruais \& Rodríguez-Monroy, 2009). They can build a "relationship risk scorecard" for their main accounts, classifying them from the most risky to the least risky (Ryals \& Knox, 2007). In order to assure the best classification and the best use of the concept of risk, it is useful to do the same exercise with three senior managers with deep knowledge of the customers and the market. Later, they can assign retention probability weights to each of the factors on the scorecard. The probability weights results will be the basis for a series of workshop discussions to finalize the LTV-WACC calculations, the final LTV calculations per customer and the customer equity in the firm.

Some risk factors that they can include in the "relationship risk scorecard" could be the following (Ryals \& Knox, 2007):

1. Overall relationship:

a. Number of customer relationships with other parts of the company. 


\section{Intangible Capital}

b. Number of business lines (products) bought by the customer.

c. Longevity of the relationship (in years).

2. Account relationship:

a. Company's relationship with the distributor (broker).

b. Quality of relationship with the customer.

c. Number of personal contacts the company has with the customer.

d. Number of personal contacts the customer has with the company.

3. Knowledge of the customer:

a. How good is the company's understanding of customer's company?

b. How good is the company's understanding of the customer's industry?

So, it is necessary to measure:

1. The risk associated with each customer.

2. Risk reduction through the diversification of the customer base.

3. Possibility of increasing switching costs in order to reduce share-of-wallet risk.

\section{Future lines of research}

In order to have a better measurement of customer equity, and to better evaluate the future cash flows, it is necessary to understand and to analyze deeply the customer-supplier relationships further reducing the uncertainty associated with this relationship. Hence, we propose to complement the customer equity analysis with the relationship equity approach as a future research line.

The value of these relationships should be analyzed from the point of view of suppliers and from the point of view of customers. Sometimes this analysis could have different results in how the value is measured due to the fact that the two sides of the relationships have different cultures, strategies, competences, How to measure customer value and its relationship with shareholder value... 
resources, history, lateral relationships, etc. In this sense, the concept of perceived value should be the issue to focus on now. In order for a relationship to be successful there has to be a common interest in some aspects between supplier portfolio management (from the customer perspective) and customer portfolio management (from the supplier perspective). Customer portfolio management is thus a useful tool for decreasing dependence on single customers and reducing cash flow volatility, and consequently enabling to evaluate LTV better. On the other hand, from a strategic point of view, the networking potential cannot be traded or easily replicated by competitors; it is complementary in the sense that it makes marketing efforts more effective and creates a barrier which maintains the competitive advantage of the firms.

In this way, this perspective complements the former one in the sense that it provides the tool to estimate future revenues (up-selling, cross-selling) and potential risk of defection in the proposed equation. So considering it merits a deeper analysis in a future article to develop it. On the other hand, we consider a very interesting issue to explore the application of the equation and mathematical models of LTV proposed in this paper to real cases of publicly traded firms. For this purpose, we would use published information with the goal of assessing the value of the firms analyzed, linking customer value to firm value.

\section{References}

BAXTER R. (2009). Reflective and formative metrics of relationship value: A commentary essay. Journal of Business Research, 62(1): 1370-1377. doi: 10.1016/j.jbusres. 2008.12.004

BERGER, P.D.; NASR, N.I. (1998). Customer lifetime value: Marketing models and applications. Journal of Interactive Marketing, 12: 17-30. doi: 10.1002/(SICI)1520-6653(199824)12:1<17::AID-DIR3>3.0.CO;2-K

BLATTBERG, R.C.; DEIGHTON, J. (1996). Manage Marketing by the customer equity test. Harvard Business Review, 74(4): 136-44.

BLATTBERG, R.C.; THOMAS, J.S. (2000). Valuing, analyzing and managing the marketing function using customer equity principles. Unpublished manuscript, Northwestern University, Evanston, II. 


\section{Intangible Capital}

Intangible Capital, 2010 - 6(2):142-161 - ISSN: 1697-9818 doi: 10.3926/ic.2010.v6n2.p142-161

DWYER, R.F. (1997). Customer lifetime value valuation to support Marketing decision making. Journal of Direct Marketing, 11(4): 6-13. doi: 10.1002/(SICl)1522-7138(199723)11:4<6: : AID-DIR3>3.0.CO;2-T

HOGAN J.E. (2001). Expected Relationship Value. Industrial Marketing Management, 30(1): 339-351. doi:10.1016/S0019-8501(01)00152-3

HWANG H.; JUNG T.; SUH E. (2004). An LTV model and customer segmentation based on customer value: a case study on the wireless telecommunication industry. Expert Systems with Applications, 26(2): 181-188. doi:10.1016/S09574174(03)00133-7

JACK S.L. (2010). Approaches to studying networks: Implications and outcomes. Journal of Business Venturing, 25(1): 120-137. doi: 10.1016/j.jbusvent.2008.10.010

JACOBS F.A.; JOHNSTON W.; KOTCHETOVA N. (2001). Customer Profitability. Industrial Marketing Management, 30: 353-363. doi:10.1016/S00198501(01)00155-9

JAIN D.; SINGH S.S. (2002). Customer Lifetime Value research in Marketing: A review and future directions. Journal of Interactive Marketing, 16(2): 34-36. doi: 10.1002/dir.10032

KIM J .; SUH E.; HWANG H. (2003). A Model for evaluating the effectiveness of CRM using the Balanced Scorecard. Journal of Interactive Marketing, 17(2): 5-19. doi: 10.1002/dir. 10051

KIM S.; JUNG T.; SUH E.; HWANG H. (2006). Customer segmentation and strategy development based on customer lifetime value: A case study. Expert Systems with Applications, 31(1): 101-107. doi:10.1016/j.eswa.2005.09.004

LECHNER C.; DOWLING M.; WELPE I. (2006). Firm networks and firm development: the role of the relational mix. Journal of Business Venturing, 21(4): 514-540. doi: 10.1016/j.jbusvent.2005.02.004

LEMON, K.N.; RUST R.T.; ZEITHAML, V.A (2001). What drives customer equity? Marketing Management, 10: 20-25. doi: 10.1016/S0019-8501(02)00225-0 


\section{Intangible Capital}

LINDGREEN A.; WYNSTRA F. (2005). Value in business markets: What do we know? Where are we going? Industrial Marketing Management, 34(7): 732-748. doi: 10.1016/j.indmarman.2006.04.005

MÖLLER K.; TÖRRÖNEN P. (2003). Business suppliers'value creation potential. A capability-based analysis. Industrial Marketing Management, 32(2): 109-118. doi: 10.1016/S0019-8501(02)00225-0

MÖLLER, K (2006). Role of competences in creating customer value: A valuecreation logic approach. Industrial Marketing Management, 35(8): 913-924. doi: 10.1016/j.indmarman.2006.04.005

MURUAIS, J.; RODRÍGUEZ MONROY, C. (2009). Hacia un enfoque de KAM eficaz. Harvard-Deusto Business Review, 91: 58-64.

PETERSEN J.A.; MCALISTER L.; REIBSTEIN D.J.; WINER R.S.; KUMAR V.; ATKINSON G. (2009). Choosing the right metrics to maximize profitability and shareholder value. Journal of Retailing, 85(1): 95-111. doi: 10.1016/j.jretai.2008.11.004

PFEI FER, P.E.; CARRAWAY, R.L. (2000). Modeling customer relationships as Markov Chains. Journal of Interactive Marketing, 14(2): 43-55. doi:10.1002/(SICI)15206653(200021) 14:2<43: : AID-DIR4>3.0.CO;2-H

REINARTZ, W.J .; KRAFFT, M.; HOYER, W.D. (2004). The customer relationship management process: Its measurement and impact on performance. Journal of Marketing Research, XLI : 293-305. doi: 10.1509/jmkr.41.3.293.35991

REINARTZ, W.J .; KUMAR, V. (2000). On the profitability of long lifetime customers: An empirical investigation and implications for Marketing. Journal of Marketing, 64: 17-35. doi: 10.1509/jmkg.64.4.17.18077

RICHARDS K.A.; JONES E. (2008). Customer relationship management: finding value drivers. Industrial Marketing Management, 37(2): 120-130. doi:10.1016/j.indmarman.2006.08.005

RIGBY, D.K.; REICHHELD, F.F.; SCHEFTER, P. (2002). Avoid the four perils of CRM. Harvard Business Review, 80(2): 101-109. 
RUST R.T.; LEMON K.N.; ZEITHAML V.A. (2000). Driving customer equity: how customer lifetime value is reshaping corporate strategy. New York: Free Press.

RYALS L.; KNOX S. (2007). Measuring and managing customer relationship risk in business markets. Industrial Marketing Management, 36(6): 823-833. doi: 10.1016/j.indmarman.2006.06.017

SAWHNEY, M.; ZABIN, J. (2002). Managing and measuring relational equity in the network economy. Journal of the Academy of Marketing Science, 30(4): 313-332. doi: $10.1177 / 009207002236908$

SCHMITTLEIN, D.C.; MORRISON, D.G.; COLOMBO, R. (1987). Counting Your Customers: Who are they and what will they do next. Management Science, 33: 1-24. doi: $10.1287 / \mathrm{mnsc} 33.1 .1$

SEGGIE S.H.; CAVUSGIL E.; PHELAN S.E. (2007). Measurement of return on marketing investment: A conceptual framework and the future of marketing metrics. Industrial Marketing Management, 36(6): 834-841. doi: 10.1016/j.indmarman.2006.11.001

STAHL H.K.; MATZLER K.; HINTERHUBER H.H. (2003). Linking customer lifetime value with shareholder value. Industrial Marketing Management, 32(4): 267-279. doi: 10.1016/S0019-8501(02)00188-8

WALTER A.; RITTER T.; GEMÜNDEN H. (2001). Value creation in Buyer-Seller relationships. Industrial Marketing Management, 30(4): 365-377. doi: 10.1016/S0019-8501(01)00156-0

Intangible Capital, 2010 (www.intangiblecapital.org)

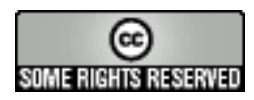

Article's contents are provided on a Attribution-Non Commercial 3.0 Creative commons license. Readers are allowed to copy, distribute and communicate article's contents, provided the author's and Intangible Capital journal's names are included. It must not be used for commercial purposes. To see the complete license contents, please visit http://creativecommons.org/licenses/by-nc/3.0/es/ 